\title{
\begin{tabular}{lll}
\hline Vol. 9 & No. 2 & June 1987 \\
\hline
\end{tabular}
}

Studies in Second

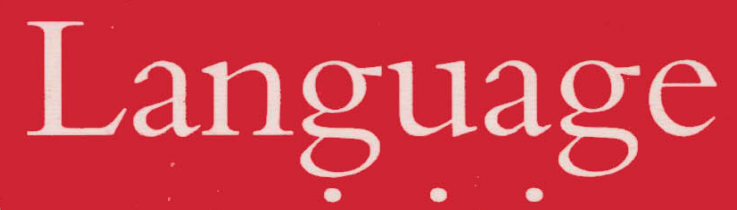

Acquisition

Special Issue

The Use and Acquisition of the Second Language Lexicon

Cambridge University

Press 


\author{
Editor, Albert Valdman, Indiana University \\ Assistant to the Editor, Molly Wieland, Indiana University
}

\title{
Editorial Board
}

Andrew Cohen (Hebrew University), Gary Cziko (University of Illinois), Alison d'Anglejan (Université de Montréal), R. J. Ellis (Ealing College of Higher Education), Susan M. Gass (Michigan State University), Gabriele Kasper (University of Aarhus), Michael Long (University of Hawaii-Manoa)

\section{Advisory Committee}

Simon Belasco (University of South Carolina), Lawrence Carrington (University of the West Indies), Robert DiPietro (University of Delaware), Harry Gradman (Indiana University), Braj Kachru (University of Illinois), Eric Kellerman (University of Nijmegen), Jürgen Meisel (Universität Hamburg), Wilga Rivers (Harvard University), Robin Scarcella (University of California, Irvine), John H. Schumann (UCLA), Mary Wan Joo Tay (National University of Singapore), Merrill Swain (Ontario Institute for Studies in Education), Renzo Titone (Roma), G. Richard Tucker (Center for Applied Linguistics)

\section{EDITORIAL POLICY}

Studies in Second Language Acquisition is devoted to problems and issues in Second Language Acquisition and Foreign Language Learning, defined broadly to include problems of language contact - interference, transfer, pidginization. While preference will be given to theoretically-oriented papers and reports of empirical research, discussions of pedagogical issues will be considered if they refer to major theoretical issues in the field. Studies in Second Language Acquisition is a refereed publication. Submitted material undergoes blind evaluation by at least two readers selected from the members of the Editorial Board, Advisory Committee, and other experts in the field. The names of all outside readers consulted will be listed in the final issue of each yearly volume.

\section{SUBSCRIPTIONS}

Studies in Second Language Acquisition (ISSN 02722631 ) is published three times a year. The subscription price, which includes postage, of Volume 9,1987 , is US $\$ 47.00$ in the U.S.A. and Canada ( $\$ 26.00$ net) for institutions; US $\$ 26.00$ in the U.S.A. and Canada $(£ 14.50)$ for individuals subscribing for their personal use. Single parts cost US $\$ 18.00$ in the U.S.A. and Canada $(£ 10.00$ net) plus postage. Institutional orders may be sent to a bookseller, agent or direct to Cambridge University Press, 32 E. 57th Street, New York, NY 10022, or outside the U.S.A. and Canada to Cambridge University Press, the Edinburgh Building, Shaftesbury Road, Cambridge CB2 2RU, England. Individuals must order direct from the Press.

Claims for missing issues should be made immediately after receipt of the next issue.

\section{COPYING}

This journal is registered with the Copyright Clearance Center, 27 Congress Street, Salem, MA 01970. Organizations in the U.S.A. who are also registered with C.C.C. may therefore copy material (beyond the limits permitted by sections 107 and 108 of U.S. copyright law) subject to payment to C.C.C. of the per-copy fee.

The Item-Fee Code for this journal is 0272-2631/87 $\$ 5.00+.00$. This consent does not extend to multiple copying for promotional or commercial purposes.
ISI Tear Service, 3501 Market Street, Philadelphia, PA 19104, U.S.A. is authorized to supply single copies of separate articles for private use only.

For all other use, permission should be sought from the New York or Cambridge office of the Cambridge University Press.

\section{ADVERTISING}

Inquiries about advertising should be sent to the Journals Promotion Department of the New York or Cam- bridge office of Cambridge University Press.

\section{(C) 1987 Cambridge University Press}




\section{TABLE OF CONTENTS}

THE USE AND ACQUISITION OF THE SECOND LANGUAGE LEXICON

Edited by Susan M. Gass

\section{ARTICLES}

Introduction Susan M. Gass

Words as Things: Development of Word Concept by Bilingual Children Ellen Bialystok

A Multiple Word Association Probe in Second Language Acquisition Research Heleen Kruse, James Pankhurst, and Michael Sharwood Smith

Lexical-Grammatical Pragmatic Indicators Shoshana Blum-Kulka and Edward A. Levenston

Perspective and Proficiency in L2 Referential Communication

Theo Bongaerts, Eric Kellerman, and Andy Bentlage

Patterns of Vocabulary Development in Foreign-Language

Learners Rolf Palmberg

The Acquisition of New Word Formation Processes in Second Language Acquisition Elite Olshtain

Lexical Constraints on Syntactic Acquisition Josh Ard and

Susan M. Gass

\section{REVIEWS}

Wierzbicka, Anna. (1985). Lexicography and conceptual analysis (Edward Gates)

Linnarud, Moira. (1986). Lexis in composition: A performance analysis of Swedish learners' written English (Claus Faerch)

Gairns, Ruth, \& Redman, Stuart. (1986). Working with words: A guide to teaching and learning vocabulary (Carolyn G. Madden) 